GTAR 2016

\title{
Increase the Ability of Self-Direction through Spiritual Counselling
}

\author{
Iip Istirahayu ${ }^{1^{*}}$, Syamsu Yusuf ${ }^{2}$, Dian Mayasari $^{3}$ \\ ${ }^{1,3}$ STKIP Singkawang, Indonesia \\ ${ }^{2}$ Indonesia University of Education, Indonesia
}

Abstract

\begin{abstract}
The aim of this research is to increase the self-directing of students through spiritual counseling. The approach that used in this study was weak experimental with one group pretest-post test design. Treatment has given by researcher four times in spiritual counseling sessions. First opening, second transition, third main, and 4th closing. Populations' are students on grade of university in Singkawang, West Borneo, Indonesia. The samples on this research are 10th students. Sampling technique used random sampling. Instrument employed to collect desired information is questionnaire self-direction with Likert scale. Data analyzed used N-Gain formula. This technique has chose because to calculate increasing of self directing students. This results shown that the increasing of Spiritual Counseling trough is student selfdirection of 0.73 (High-g category).
\end{abstract}

(C) 2016 The Authors. Published by Global Illuminators. This is an open access article under the CC BY-NC-ND license

(http://creativecommons.org/licenses/by-nc-nd/4.0/)

Peer-review under responsibility of the Scientific \& Review committee of GTAR-2016.

Keywords: Spiritual Counseling, Self-Direction, Increase

\section{Introduction}

Humans are social creatures. In life, people always relate to other human beings. A relationship with others requires interpersonal competence, the ability to relate to others. People who have good interpersonal competency is influenced by competence intrapersonal. One intrapersonal competency that need is self-direction.

Self-direction is the ability to direct him and take full responsibility for the consequences of his behavior. Results research Eliasa (2010), self-direction is an indicator of the most widely experienced problems within the competence of intrapersonal. Dahlan study (2011) found $13.68 \%$ of 585 students, explaining that the students have a purpose in life that is unclear and unfocused.

Based on observations on some students in some universities, student confusion to get a job would prefer to be unemployed, less able to entrepreneurship, and have not been able to direct itself to decide a family or work after graduation.

Findings of observation and some previous studies, it was concluded that the low self direction will result in individuals less able to make decisions, have not been able to deal with failure, yet disciplined and have not been able to control himself.

Education has an important role in life. Spiritual counseling is one area of education that play a role in shaping the human character. Spirituality is a separate line of development, an attitude (such as openness or love) that can reach a peak level involving experience. Spiritual counseling defined as a way of interacting between practitioners counseling in the therapeutic process between humans, which are in themselves individually odyssey as human beings.

Turliuc explain the development of ever-increasing popularity of spiritual counseling. Human needs (students) to spirituality are absolute. In the European world, more than $80 \%$ of the populations adhere to one religion. Mahajan (2008), women are infertile feel mentally healthy because by $49.3 \%$ influenced by factors intrinsic religiosity, sexual satisfaction, and a good family support.

*All correspondence related to this article should be directed to Iip Istirahayu, STKIP Singkawang, Indonesia 


\section{Objective of the Study}

Based on the background of existing problems, the purpose of this study was to determine the increase in the ability of self-direction student through spiritual counseling.

\section{Literature Review}

The use of scripture (writing the book) or religious bibliotherapy including one spiritual counseling technique. Miller (2003) believes that the use of scripture will help the client see the problem differently, understand the scriptures better, and look for a higher power. The story is found in the holy book can be used as a guide to life. The verse in Scripture also contains guidance of life (Najati, 2005).

Makhdlori (2007) reveals something "magical" or mystical, spiritual power-tallest in the metaphysical sense of the contents of $\mathrm{Al}$-Quran. Verses resembles a talisman that protects human being knows the secrets in it. The physical presence of the Qur'an bring blessing to people who believe in it. If a person facing life's difficulties, mental shock such as stress, depression, syndrome, it will recover with the power of "magic" that spiritual in certain verses of the holy power of nature transcendent. The Word of God in verse 204 of surah Al-Araf meaning: "and when the Qur'an is read, then listen carefully, and consider calmly that ye may receive mercy". The Qur'an is the source of the laws that govern everyday human life and a source of knowledge for human intellectual activity, both material and nonmaterial.

Miller (2003) cite the explanation of some of the following experts. "Prayer is a core part of religions practice and prayer has many different from different due to individual differences and culture (Wulff, 1997). As McCullough and Larson (1999) state: prayer is made up actions, thoughts, and attitudes that connect a person to the sacred realm. Prayer can be reviewed restaurants as talking and the act of praying may carouse the client to slow down his or her busy life or and find that he or she receive information about his or her answers to life question (Beevar; 1997). Poloma and Pandelton (1989. 1991) describe four types or prayer that they label meditative, ritualistic, petitioner, and colloquial.

Willber (Burke, 2005) Spirituality Involves the highest levels of the developmental lines, the sum total of the developmental lines, itself a separate developmental lines, an attitude (such as openness or love) that you can have a whatever stage you are at basically peak involve; experiences.

\section{Self-Direction}

Self-direction has meaning as a power that gives direction for a person in his life and the full responsibility for the consequences of his behavior. The more capable a person directs his behavior, it is increasingly likely to live life effectively and avoid situations that could interfere with the trip of his life. Three behaviors are important for selfdirection, self-confidence, self-reliance, and self-control (Cavanagh and Levitov, 2002).

\section{Self-confidence}

Self-confidence is extremely important in almost every aspect of our lives, yet so many people struggle to find it. sadly, this can be a vicious circle: People who lack self-confidence can find it difficult to become successful. Level of self-confidence can show in many ways; your body language, how you speak, what you say, and so on (Manktelow \& Carlson, 2009).

\section{Self-Reliance}

Self-reliance is a part of self-direction. The more people can create a situation in order to be able to meet their needs, then he will be able to direct their behavior. Others will control direction of one's life, if someone is too dependent on the fulfillment of the needs of others. People who lack self-reliance, will encounter several problems, among others: (1) feel resentment / anger at myself for not able to meet their own needs; (2) find difficulty in fulfilling all tasks as an observer in a position to sources of psychological needs; and (3) experiencing interpersonal problems (Cavanagh).

\section{Self-control}

Self-control is an important part of self-direction because of self-control helps people in connecting between energy and the rules to guide his own life. Self control sound based on good internal communication. Desire or impulse that comes to the mind is connected with the possible consequences and a form needs to manifest the values of higher subjectively (Cavanagh, 2002). 


\section{Research Model}

Below is the research a model of the weak experiment. The approach used in the research is quantitative with one group pretest-posttest design. The research was conducted by doing preliminary study, pretest, giving intervention of spiritual counseling in four times session, posttest, and analyzing the data.

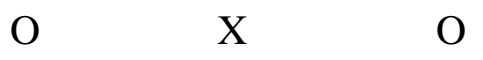

Creswell, (2012)

Figure 1: Research Model

Data Analysis

Descriptive Statistics can be seen in the below

$<\mathrm{g}>\equiv \%<\mathrm{G}>/ \%<\mathrm{G}>\max =(\%<\mathrm{Sf}>-\%<\mathrm{Si}>) /(100-<\mathrm{Si}>)$

"High-g" courses as those with $(<\mathrm{g}\rangle)>0.7$;

"Medium-g" courses as those with $0.7>(<\mathrm{g}\rangle)>0.3$;

"Low-g" courses as those with $(<\mathrm{g}\rangle)<0.3$.

Hake (2012)

The description of analyzing shown on the Table

Table 1

$N$-Gain (Increasing)

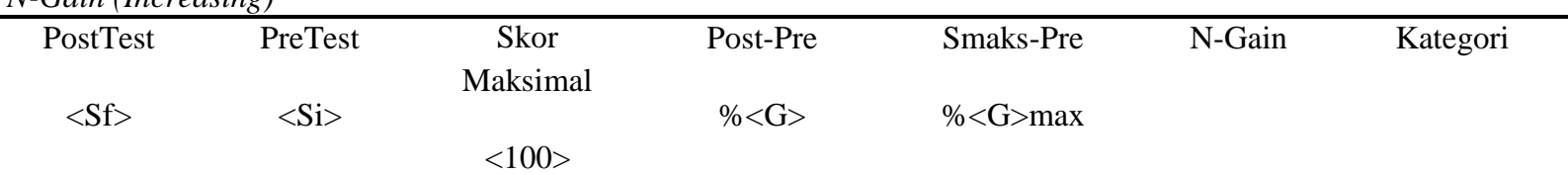

\begin{tabular}{cccccccc}
\hline 45 & 44 & 48 & 1 & 4 & 0.25 & Low-g \\
39 & 35 & 48 & 4 & 13 & 0.31 & Medium-g \\
\hline 45 & 40 & 48 & 5 & 8 & 0.63 & Medium-g \\
\hline 51 & 25 & 48 & 26 & 23 & 1.13 & High-g \\
42 & 31 & 48 & 11 & 17 & 0.65 & Medium-g \\
\hline 42 & 30 & 48 & 12 & 18 & 0.67 & Medium-g \\
\hline 48 & 39 & 48 & 2 & 9 & 0.22 & Low-g \\
\hline 39 & 29 & 48 & 19 & 19 & 1 & High-g \\
\hline 48 & 31 & 48 & 8 & 17 & 0.47 & Medium-g \\
\hline 40 & 333 & 480 & 19 & 19 & 1 & High-g \\
\hline
\end{tabular}




\section{Discussion}

Through spiritual counseling, self-direction capabilities can be enhanced by good students that $\mathrm{g}=0.73$ (73\%). Increasing student 2nd medium-g, 5th increasing medium-g, and Third student have increasing high-g. That is, through spiritual counseling, students are quite capable of improving self-confidences, self-reliance, and self control as much as 2 people. Students are able to either 5 people, and students were able to very well by 3 people.

Conclusion

Spiritual counseling can do increasing ability $73 \%$ self-direction students.

\section{References}

Cavanagh, M. E. (1982). The counseling experience. Monterey California: Brooks/Cole Publishing Company.

Creswell, John W. (2012). Educational research: Planning, conducting, and evaluating quantitative and qualitative research. Boston: Pearson Education.

Emerson, B. L., \& Hinkle, J. S. (1998). A police peer counselor uses reality therapy. Journal of Reality Therapy, 8(1), 2-5.

Hake, R. R. (1999). Analyzing change/gain scores. Unpublished.[online] URL: http://www. physics. indiana. edu/ sdi/AnalyzingChange-Gain. pdf.

Lines, D. (2006). Spirituality in counseling and psychotherapy. London: SAGE Publication Ltd.

Manktelow, J., et al. (2009). Building self-confidence believe in your-self, and find success. Retrived from: http://www.mindtools.com/selfconf.html

Richards, P. \& Bergin, A. E. (2006). A spiritual strategy for counseling and psychotherapy, Washington, D.C, US: American Psychological Association.

Yusuf, S. L.N. \& Nurihsan, A J. (2006). The cornerstone of guidance and counseling, Bandung: PT. Remaja Rosdakarya.

Yusuf, S. L. N. (2009). Theistic spiritual counseling, Bandung: Rizki Press. 